Reprod. Nutr. Dévelop., 1983, 23 (5), 875-881.

\title{
Activity of several enzymes of amino acid catabolism in the liver of rats fed protein as a meal
}

\author{
Geneviève BOURDEL, Yvonne HITIER, Bernard LARDEUX, \\ Anik GIRARD-GLOBA
}

with the technical assistance of Marguerite FORESTIER, Betty GOUHOT and Claude KHOL

Centre de Recherches sur la Nutrition, C.N.R.S.,

9, rue Jules-Hetzel, 92190 Meudon-Bellevue, France.

Summary. Rats having a protein-free diet available ad libitum were fed a daily casein meal at the begining of either the light-or the dark-phase of the day. A control group received a mixed-diet ad libitum. In all three groups, daily food ingestion was the same and casein corresponded to $12 \%$ of total intake. Liver activities of alanine, aspartate, ornithine and tyrosine aminotransferase, ornithine decarboxylase and serine dehydratase were assessed. In mixed-fed controls, all activities were low. Tyrosine aminotransferase and ornithine decarboxylase exhibited clear circadian rhythms of low amplitude. Feeding casein as a concentrated meal had no effect on aspartate aminotransferase. It depressed alanine aminotransferase and serine dehydratase activities. Tyrosine aminotransferase and ornithine decarboxylase exhibited rapid and strong stimulatory responses but, within 12 hours, returned to levels similar to those observed in mixed-fed controls. Ornithine aminotransferase was increased in the group receiving the casein meal during the light phase. It is concluded that the capacity for amino acid catabolism remains low in separately-fed animals, and that only tyrosine and especially ornithine, which may become limiting for urea synthesis, are actively metabolized. Thus, when high fluxes of amino acids reach the liver following the absorption of the casein meal, more amino acids are available for incorporation into newly synthesized proteins.

\section{Introduction.}

In separate feeding, the daily protein allowance is given apart from the rest of the diet in the form of a meal administered at a definite time of the day (GirardGloba and Bourdel, 1973 ; Peret, Chanez and Macaire, 1973). Since the meal is provided as a protein concentrate $(70 \%$ casein), its digestion causes portal aminoacidemia to rise to values usually found only when high-protein diets are fed ; however, this elevation is only temporary and not constant as in the case of protein-rich mixed-feeding (Bourdel et al., 1981a ; Rémésy, Demigné and Aufrère, 1978).

In rats adapted to high-protein diets, Peters and Peters (1972) did not observe any stimulation of overall hepatic protein synthesis. The reason for this 
lack of effect was partly due to the induction of enzymes of amino acid catabolism in the liver (Harper, 1965 ; Szepesi and Freedland, 1968 ; Pestaña, 1969 ; Mauron, Mottu and Spohr, 1973 ; Yanagi, Campbell and Potter, 1975) and to an increase in the capacity for ureogenesis (Schimke, 1962). On the contrary, even after a 4-week adaptation period, the ingestion of a protein meal fed separately can induce an important increase in liver protein synthesis lover 3-fold within 1 h) (Lardeux, Bourdel and Girard-Globa, 1978). This observation led to the conclusion that, in separate feeding, amino acids entering the liver are taken up for synthesis instead of being catabolized. This conclusion implied that enzymes of amino acid catabolism are not as strongly induced by separate feeding as they are by high-protein diets. The aim of present work was to verify this hypothesis. Six enzymes known to be adaptive and having different cellular localizations were selected: serine dehydratase (EC 4.2.1.13), tyrosine aminotransferase (EC 2.6.1.5), ornithine decarboxylase (EC 4.1.1.17) which are cytosolic, alanine aminotransferase (EC 2.6.1.2) which is mainly cytosolic, aspartate aminotransferase (EC 2.6.1.1) which is equally distributed between cytosol and mitochondria, and ornithine aminotransferase (EC 2.6.1.13) which is strictly mitochondrial. Alanine aminotransferase and serine dehydratase were chosen because they mediate the deamination of 3 amino acids which form large pools in the liver: alanine, serine and threonine. Aspartate aminotransferase was selected because of its close link with alanine aminotransferase (De Rosa and Swick, 1975). Tyrosine aminotransferase was thought to be of interest since, like ornithine decarboxylase, it has a short half-life and is thus sensitive to variations in protein synthetic activity. Ornithine decarboxylase is' related to protein anabolism by its involvement in the production of polyamines (Russel and Snyder, 1968, 1969 ; Fausto, 1969 ; Stevens, 1970) ; ornithine aminotransferase is also linked to anabolic processes (Morris and Peraino, 1976) as it regulates ornithine availibility at the mitochondrial level, thereby controlling ureogenesis (Krebs, Hems and Lund, 1973 ; McGivan, Bradford and Beavis, 1977 ; Cohen, Cheung and Raijman, 1980.

\section{Materials and methods}

Three groups of adult male rats (Sprague-Dawley) weighing $200 \mathrm{~g}$ were kept in individual wire-bottomed cages at $23^{\circ} \mathrm{C}$ on a light cycle of $12 / 12$ with lights-on at 07.00 . The control group was fed a mixed diet containing casein $12 \%$, sucrose $20 \%$, starch $53 \%$, peanut oil $8 \%$, cellullose $2 \%$, salts and vitamins $5 \%$. In the other 2 groups, casein was fed as a meal given either at $09.00 \mathrm{~h}(2 \mathrm{hrs}$ after the onset of light : SF09) or at $21.00 \mathrm{~h}$ ( $2 \mathrm{hrs}$ after the onset of darkness : SF21). The meals, calculated so as to match the amount of casein spontaneously ingested by mixed-fed controls, amounted to $2.25 \mathrm{~g} /$ casein/day given in the form of $3.2 \mathrm{~g}$ of a concentrate containing $70 \%$ casein, $20 \%$ starch and $10 \%$ sucrose. The other components of the diet were provided ad libitum as a protein-free mixture $165 \%$ starch with sucrose, peanut oil, cellulose, minerals and vitamins as above).

After a 4-week adaptation period, 6 animals in each group were killed by decapitation at 8 time-points regularly spaced over a 24-h cycle. In each of the 
two separately-fed groups, one additional lot of 6 rats was killed $1 \mathrm{~h}$ after the protein meal, i.e. at 10.00 and $22.00 \mathrm{~h}$ for SF09 and SF21, respectively. The livers were rapidly excized and cut into weighed aliquots, frozen in liquid nitrogen and then stored at $-40^{\circ} \mathrm{C}$ pending assay.

The enzymes were assayed according the following methods : Schwartz (1971) for aspartate aminotransferase (Asp-AT), Segal and Matsuzawa (1970) for alanine aminotransferase (Ala-AT), Diamondstone (1966) for tyrosine aminotransferase (Tyr-AT), Morris and Peraino (1976) for ornithine aminotransferase (Orn-AT), Snell and Walker (1974) for serine dehydratase (Ser-DH) and Russel and Snyder (1968) for ornithine decarboxylase (Orn-DC). Enzyme activity was expressed in $\mu$ moles of substrates utilized per min for Asp-AT, Ala-AT and Ser-DH, as $\mu$ moles of product formed per min for Tyr-AT and Orn-AT and as nanomoles of $\mathrm{CO}_{2}$ liberated per min for Orn-DC.

\section{Results.}

Mean daily food intake, similar in the three experimental groups, amounted to $17.9,18.2$ and $18.6 \mathrm{~g} /$ day in control, SF09 and SF21 animals, respectively. Separately-fed animals ate their protein meal in less than $30 \mathrm{~min}$. The timing of the protein meal did not interfere with the rhythm of spontaneous ingestion of the protein-free mixture which remained mainly nocturnal. Therefore, the protein meal was eaten either at the beginning of $8 \mathrm{~h}$ of relative fast in the SF09 group or during the course of active feeding in the SF21 group. The casein meal of SF09 animals had little chance of being diluted after ingestion, while in the SF21 group it was rapidly diluted by increasing quantities of carbohydrate reaching the stomach.

Asp-AT, Ala-AT, Orn-AT and Ser-DH exhibited no circadian variations, so results were expressed as mean levels over $24 \mathrm{~h}$ (table 1). Except for Asp-AT, all levels of activity were affected by separate-feeding. Ala-AT, and especially Ser-DH, were significantly depressed in both groups of separately-fed animals, Ala-AT by $20 \%$ and Ser-DH by over $60 \%$; Orn-AT was increased by $19 \%$, but only by feeding the casein meal at $09.00 \mathrm{~h}$.

Orn-DC and Tyr-AT had a clear parallel circadian rhythmicity in the three experimental groups (fig. 1, panels A and B). As expected, with mixed-feeding,

\section{TABLE 1}

Mean level of enzyme activities over 24 hrs in mixed-fed controls and in separately-fed rats

\begin{tabular}{lllll}
\hline & Asp-AT & Ala-AT* & Orn-AT* & Ser-DH $^{*}$ \\
\hline Controls (mixed feeding) $\ldots$ & $231 \pm 7^{\mathrm{a}}$ & $13.2 \pm 0.5^{\mathrm{a}}$ & $0.44 \pm 0.02^{\mathrm{a}}$ & $0.71 \pm 0.07^{\mathrm{a}}$ \\
SF09 $\ldots \ldots \ldots \ldots \ldots \ldots \ldots \ldots$ & $230 \pm 9^{\mathrm{a}}$ & $10.6 \pm 0.4^{\mathrm{b}}$ & $0.53 \pm 0.02^{\mathrm{b}}$ & $0.29 \pm 0.04^{\mathrm{b}}$ \\
SF21 $\ldots \ldots \ldots \ldots \ldots \ldots \ldots$ & $246 \pm 12^{\mathrm{a}}$ & $10.7 \pm 0.4^{\mathrm{b}}$ & $0.41 \pm 0.02^{\mathrm{a}}$ & $0.23 \pm 0.03^{\mathrm{b}}$
\end{tabular}

* Values are the mean of measurements \pm SEM, on 48 rats sacrificed over $24 \mathrm{hrs} \mathrm{U} / \mathrm{g}$ liver (see Materials and Methods). In each column, values with different superscripts are significantly different from each other $(P<0.05)$. 

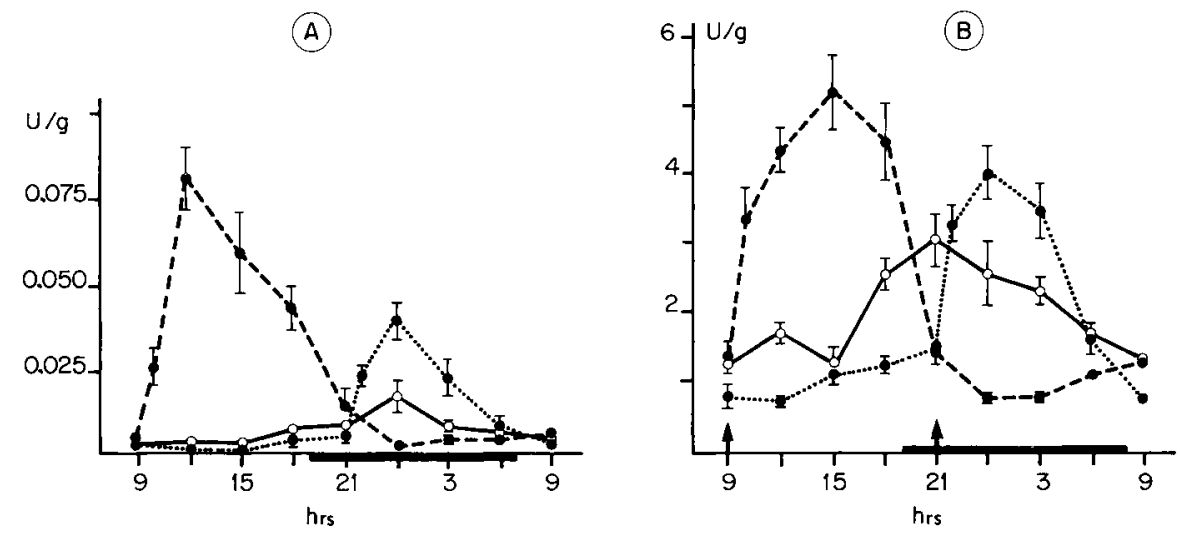

FIG. 1. - Circadian variations of ornithine decarboxylase (Panel A) and of tyrosine aminotransferase (Panel B) in the liver. $\mathrm{O}$ ___ $\mathrm{O}$ : controls ; - - - : SF09; represents the mean of 6 determinations \pm SEM. Arrows indicate timing of casein-meal for SF09 and SF21 groups. For definition of units see Materials and Methods.

these enzymes started rising before the end of the light-period as the animals resumed eating, reaching their respective maxima at $24.00 \mathrm{~h}$ (Orn-DC) and $21.00 \mathrm{~h}$ (Tyr-AT); they decreased during the second part of the dark period in spite of continued eating. The ratio between peak and basal values was of the order of 7 for Orn-DC and of 2 for Tyr-AT. Whether at 09.00 or $21.00 \mathrm{~h}$, casein ingestion in separately-fed animals was followed by a sharp increase in the activity of both enzymes. At first, induction was of comparable magnitude in both groups; $1 \mathrm{~h}$ after protein ingestion, Orn-DC increased 5.8- and 3.8-fold and Tyr-AT 2.5 and 2.3-fold in SF09 and SF21 animals, respectively. Later, however, it was clear that the meal had a greater and more sustained inductive capacity during the light-phase than during the dark-phase. The difference was most pronounced for SF09 Orn-DC which peaked at more than twice the maximal SF21 value, while SF09 Tyr-AT was only $25 \%$ above the SF21 level at maximal stimulation. It should be noted that both enzymes subsequently returned to basal levels well within the range of the controls.

\section{Discussion.}

All the enzymes studied in the course of the present experiment are considered to be adaptive and have been shown to vary with dietary protein content. II has been suggested that liver amino acid concentration is an important factor in the regulation of this type of enzyme (Rosen et al., 1963). The low levels of activity and small amplitude of circadian variations observed in mixed-fed controls where thus expected since the low casein content $(12 \%)$ of the diet allowed but a limited supply of dietary amino acid to the liver. Even after 4 weeks of adaptation, the same amount of casein administered as a concentrated meal, 
induced an abrupt increase in liver amino acids (Bourdel et al., 1981b). Our present results show that the daily recurrence of this periodical increase in concentration is not effective in promoting any permanent rise in enzyme activity, i.e. Asp-AT was unaffected in both groups of separately-fed rats and Ala-AT and SerDH were significantly depressed. After stimulation, even Tyr-AT and Orn-DC returned to levels in the range of those observed in mixed-fed controls.

We have shown elsewhere (Lardeux, Bourdel and Girard-Globa, 1978) that ingestion of the casein meal is followed by a stimulation of liver protein synthesis. On the grounds that Ala-AT is always depressed under conditions of stimulated liver growth, Rosen et al. (1963), Harding, Rosen and Nichol (1966a, b) postulated an inverse relationship between transamination and protein synthesis; our finding that Ser-DH is considerably depressed should add weight to this argument. But, at first, the results obtained with Tyr-AT do not seem to fit into this scheme. Indeed, in separately-fed animals, Tyr-AT exhibited strong stimulatory responses which developed in parallel with stimulation of protein synthesis and covered the period of elevated levels of portal amino acidemia (Bourdel et al., 1981a). Unlike the other transaminating enzymes studied, Tyr-AT appeared to respond to the discontinuous increase in amino acid supply, perhaps due to its short half-life. Whether this effect is exerted solely through the concentration of amino acids in the hepatocyte or is also hormonally mediated remains to be clarified.

While the metabolic implication of the acute stimulation of Tyr-AT remains obscure, that of Orn-DC appears to be important since the substrate, ornithine, is rate-limiting in the production of urea (Krebs, Hems and Lund, 1973 ; McGivan, Bradford and Beavis, 1977 ; Cohen, Cheung and Raijman, 1980). This lessening of ornithine availability is most probably potentiated in SF09 rats by the existence of a moderate but significant elevation of Orn-AT, resulting in more diversion of ornithine into glutamate synthesis at the mitochondrial level. Just before the meal, ornithine in SF09 animals (Bourdel et al., 1981b) was found to amount to $0.17 \mu \mathrm{mole} / \mathrm{g}$ liver, a value well within the range reported by Saheki, Katsunuma and Sase (1977) for animals fed a $5 \%$ protein diet. Liver ornithine rose $129 \%$ within the hour following the meal but then decreased steadily and was back to $0.20 \mu \mathrm{mole} / \mathrm{g}$ liver 9 hours later, despite a persistantly high portal flux of ornithine, citrulline and above all of arginine. The combined action of the two enzymes should concur to restrain stimulation of urea production during the period of acute transport of amino acid to the liver.

With the notable exception of Tyr-AT, which is known to respond to specific and ambiguous regulatory processes, the overall response of the liver to recurring high influx of amino acids unexpectedly tends towards sparing rather than catabolism. This probably contributes to explain the intense stimulation of protein synthesis observed under these conditions.

Reçu en janvier 1983.

Accepté en avril 1983.

Résumé. Modulations de l'activité hépatique de certaines enzymes du catabolisme des acides aminés par la chronologie de l'ingestion de protéines.

On a comparé le niveau hépatique de plusieurs enzymes du catabolisme des acides aminés chez 3 groupes de rats maintenus en éclairage 12/12 et ingérant la même quantité 
journalière de caséine administrée sous forme d'une ration mixte (témoins) ou d'un repas concentré (alimentation séparée). En alimentation séparée, le repas de caséine est administré soit durant la période diurne $(09 \mathrm{~h})$ soit durant la période nocturne $(21 \mathrm{~h})$; une ration protéiprive de complément est offerte ad libitum. Les activités enzymatiques mesurées ont été les suivantes : transaminase de l'acide aspartique, de l'alanine, de l'ornithine et de la tyrosine, ornithine décarboxylase et sérine déhydratase. Comparées aux niveaux enzymatiques des témoins, les activités de l'alanine aminotransférase et de la sérine déhydratase sont déprimées en alimentation séparée, l'activité de l'aspartate aminotransférase restant inchangée. L'activité de l'ornithine décarboxylase et celle de la tyrosine aminotransférase sont très fortement stimulées après la consommation du repas protéique mais elles retournent en $12 \mathrm{~h}$ à des niveaux de base qui sont comparables à ceux des témoins. L'ornithine aminotransférase n'est significativement augmentée que chez les animaux recevant le repas protéique pendant la période diurne. En alimentation séparée, la capacité du foie à cataboliser les acides aminés absorbés (tyrosine exceptée) reste basse et ceux-ci sont donc préférentiellement utilisés pour la synthèse protéique.

\section{References}

BOURDEL G., KANDE J., ROBIN D., ROBIN P., 1981a. Quantitative and qualitative circadian variations of amino acid intestinal efflux in mixed-fed and in protein-meal fed rats. J. Nutr., 111, 1528-1535.

BOURDEL G., ROBIN D., ROBIN P., KANDE J., 1981b. Circadian variations of liver free amino acid content in mixed-fed and protein-mean fed rats. J. Nutr., 111, 1536-1542.

COHEN N.S., CHEUNG C. W., RAIJMAN L., 1980. The effects of ornithine on mitochondrial carbamyl phosphate synthesis. J. biol. Chem., 255, 10248-10255.

DE ROSA G., SWICK R. W., 1975. Metabolic implications of distribution of alanine aminotransferase isoenzymes. J. biol. Chem., 250, 7961-7967.

DIAMONDSTONE T. I., 1966. Assay of tyrosine aminotransferase activity by conversion of p-hydrophenylpyruvate and p-hydroxybenzaldehyde. Anal. Biochem., 16, 395-401.

FAUSTO N., 1969. Studies on ornithine decarboxylase activity in normal regenerating livers. Biochim. biophys. Acta, 190, 193-201.

GIRARD-GLOBA A., BOURDEL G., 1973. Physiological regulation of the circadian rhythm in hepatic tyrosine transaminase : schedule of protein ingestion as a determinant factor. $d$. Nutr., 103, 251-256.

HARDING H. R., ROSEN F., NICHOL C. A., 1966a. Effect of partial hepatectomy and pregnancy on tumor growth and alanine- $\alpha$-ketoglutarate activity. Proc. Soc. exp. Biol. Med., 122, 561565.

HARDING H. R., ROSEN F., NICHOL C. A., 1966b. Effects of pregnancy on several cortisolresponsive enzymes in rat liver. Am. J. Physiol., 211, 1361-1365.

HARPER A. E., 1965 . Effect of variations in protein intake on enzymes of amino acid metabolism. Can. J. Biochem., 43, 1589-1603.

KREBS H. A., HEMS R., LUND P., 1973. Some regulatory mechanisms in the synthesis of urea in the mammalian liver. Adv. Enzyme Regul., 11, 361-377.

LARDEUX B., BOURDEL G., GIRARD-GLOBA A., 1978. Regulation of hepatic synthesis of proteins by the chronology of protein ingestion. Biochim. biophys. Acta, 518, 113-124.

MAURON J., MOTTU F., SPOHR G., 1973. Reciprocal induction and repression of serine dehydratase and phosphoglycerate dehydrogenase by proteins and dietary-essential amino acids in rat liver. Eur. J. Biochem., 32, 331-342.

McGIVAN J. D., BRADFORD N. M., BEAVIS A. D., 1977. Factors influencing the activity of ornithine aminotransferase in isolated rat liver mitochondria. Biochem. J., 162, 147-156.

MORRIS J. E., PERAINO C., 1976. Immunochemical studies of serine dehydratase and ornithine aminotransferase regulation in rat liver in vivo. J. biol. Chem., 251, 2571-2578.

PERET J., MACAIRE I., CHANEZ M., 1973. Schedule of protein ingestion nitrogen and energy utilisation and circadian rhythms of hepatic glycogen, plasma corticosterone and insulin in rats. J. Nutr., 103, 866-874. 
PESTANA A., 1969. Dietary and hormonal control of enzymes of amino acid catabolism in liver. Eur. J. Biochem., 11, 400-404.

PETERS T. P. Jr., PETERS J. C., 1972. The biosynthesis of rat albumin. VI. Intracellular transport of albumin and liver protein synthesis in vivo under various physiological conditions. J. biol. Chem., 247, 3858-3863.

RÉMÉSY C., DEMIGNÉ C., AUFRÉRE P., 1978. ' Inter-organ relationships between glucose, lactate and amino acids in rats fed high-carbohydrate or high-protein diets. Biochem. J., 170, 321-329.

ROSEN F., HARDING H. R., MILHOLLAND R. J., NICHOL C. A., 1963. Glucocorticoids and transaminase activity. VI. Comparison of the adaptive increases of alanine- and tyrosine- $\alpha$ ketoglutarate transaminases. J. biol. Chem., 238, 3725-3729.

RUSSEL D. H., SNYDER S. H., 1968. Amine synthesis in rapidly growing tissues: ornithine decarboxylase activity in regenerating rat liver, chick embryo and various tumors. Proc. nat. Acad. Sci. U.S., 60, 1420-1427.

RUSSEL D. H., SNYDER S. H., 1969. Amine synthesis in regenerating rat liver : effect of hypophysectomy and growth hormone on ornithine decarboxylase. Endocrinology, 84, 223-228.

SAHEKY T., KATSUNUMA T., SASE M., 1977. Regulation of urea synthesis in rat liver. J. Biochem., 82, 551-558.

SCHIMKE R. T., 1962. Adaptive characteristics of urea cycle enzymes in the rat. J. biol. Chem., 237. 459-468.

SCHWARTZ M. K., 1971. Clinical aspects of aspartate and alanine aminotransferase, 866-875. In COLOWICK S. P., KAPLAN N. O., Methods in enzymology, 17b, Acad. Press, New York.

SEGAL H. L., MATSUZAWA T., 1970. L-Alanine aminotransferase (rat liver), 153-159. In COLOWICK S. P., KAPLAN N. O., Methods in enzymology, 17a, Acad. Press, New York.

SNELL K., WALKER D. G., 1974. Regulation of hepatic L-serine dehydratase and L-serine pyruvate aminotransferase in the developing neonatal rat. Biochem. J., 144, 519-531.

STEVENS H. J., 1970. The biochemical role of naturally occurring polyamines in nucleic acid synthesis. Biol. Rev., 45, 201-241.

SZEPESI B., FREEDLAND R. A., 1968. Time-course of changes in rat liver enzyme activities after initiation of a high-protein regimen. J. Nutr., 94, 463-468.

YANAGI S., CAMPBELL H. A., POTTER V. R., 1975. Diurnal variations in activity of four pyridoxal enzymes in rat liver during metabolic transition from high-carbohydrate to high-protein diet. Life Sci, 17, 1411-1422. 